\title{
Temperature effect on expression of recombinant human prethrombin-2 in Escherichia coli BL21(DE3) ArcticExpress
}

\author{
Saronom Silaban ${ }^{1,}$, , Murniaty Simorangkir ${ }^{1}$, Shabarni Gaffar ${ }^{2}$, Iman Permana \\ Maksum $^{2}$ and Toto Subroto ${ }^{2}$ \\ 'Department of Chemistry, Universitas Negeri Medan, Medan 20221, Indonesia \\ ${ }^{2}$ Department of Chemistry, Universitas Padjadjaran, Jatinangor, Indonesia
}

${ }^{*}$ Corresponding author: (SS), saronomsilaban@unimed.ac.id

DOI: 10.24114/jpkim.vlli3.15779

Received: 26 September 2019; Accepted: 29 November 2019

\begin{abstract}
:
Many proteins produced in $E$. coli accumulate in inclusion bodies. This study aims to detect the role of temperature in reducing the formation of inclusion bodies during recombinant human prethrombin-2expressed in E. coli BL2l (DE3) Arctic Express host. In this study, we created a host growth curve to find out the right time to add an inducer. The inducer used in our experiment was IPTG $0.1 \mathrm{mM}$. The fermentation process use a temperature of $12^{\circ} \mathrm{C}$ and $22^{\circ} \mathrm{C}$. The results showed that recombinant human prethrombin-2 was successfully expressed as protein soluble using an optimum temperature of $12^{\circ} \mathrm{C}$ in $E$. coli BL21 (DE3) Arctic Express. It was indicated from the $63 \mathrm{kDa}$ protein band obtained from the soluble fraction on SDS-PAGE. The higher temperature of fermentation increased the amount of protein in the insoluble fraction due. It concluded that the fermentation temperature affect the rate of prethrombin-2 expression.
\end{abstract}

Keywords: $\quad$ E. coli BL2l(DE3) ArcticExpress, prethrombin-2, soluble, temperature

\section{Introduction}

The protease $\alpha$-thrombin is a key enzyme that functions both as a procoagulant and anticoagulant. Thrombin can be potentially applied in replacing suture technic (Spotnitz and Prabhu, 2005). Fibrin glue as a bioadhesive material composed of fibrinogen, thrombin, calcium chloride and factor XIII, is designed to resemble the final stages of coagulation by forming a fibrin clot. When used in wounds, these exogenous components can help endogenous proteins to reach hemostasis (Laurens, 2006). The principle is that fibrinogen is converted into fibrin monomers by thrombin, then fibrin monomers are modified by factor XIII and calcium chloride becomes a fibrin polymer as the final form of fibrin clots through cross-linking (Bonatti et al. 2007).

Prethrombin-2 (a single polypeptide of 308 residues which corresponding to residues from Thr272 to Glu579 in prothrombin), which is a product produced by the removal of the Gla domain and two kringle domains from prothrombin, is known to be the smallest single-chain precursor to $\alpha$-thrombin (Choi et al. 1989; Yonemura et al. 2004). Prethrombin-2, structurally has one glycosylation site (at Asn373) and four disulphide bonds (Cys293-Cys439, Cys348-Cys364, Cys493-Cys507, and Cys521-Cys551) (Soejima et al., 2001). Pretrombin-2 can be converted to thrombin by FXa enzyme activators (Owen et al. 1974), or with ecarin, namely metalloprotease in the venom of snake Echis carinatus species (So et al. 1992; DiBella et al. 1995; Jonebring et al. 2012; Yonemura et al. 2004; Subroto et al. 2016).

In plasma, thrombin is formed from prothrombin which consists of several domains, whereas recombinant thrombin usually originates from the expression of the prethrombin-2 gene. 
Production of recombinant thrombin precursors has also been described in mammalian Chinese hamster ovary cells, e.g., meizothrombin (Côté et al. 1994), prethrombin-1 (Bishop et al. 2006), and prethrombin-2 (Russo et al. 1997).There are also attempts to prepare an active recombinant human thrombin with the use of $E$. coli expression. E. coli remains the system of first-choice for expressing proteins, as it is cheap, easy to be handled, and has short-life cycle (Cabrita et al. 2006). Additionally, the genome of $E$. coli well studied, so it can be easily to be manipulated. This system remains to be one of the simplest and most preferred bacterial expression systems for heterologous expression of proteins for academic researches as well as of industrial and therapeutic recombinant proteins (Chen, 2012; Osadska et al. 2014). However, inability of $E$. coli to express proteins with high molecular weight, disulphide bond rich, or posttranslational modification become a bottleneck.Prethrombin-2 had previously been expressed in E. coli (Choi et al. 1989; So et al. 1992; DiBella et al. 1995; Soejima et al. 2001; Silaban et al. 2015; ; Sllaban et al. 2017).

Soejima et al. (2001), reported a new method of easy expression and efficient refolding of recombinant human prethrombin-2 using an $E$. coli expression system, which could be usable also for the pharmaceutical industry. The final yield of purified prethrombin-2 was $0.5-1 \%$, which means that from 1 liter of $E$. coli bacterial culture only $1 \mathrm{mg}$ of the recombinant protein could be recovered. Prethrombin-2 is expressed in $E$. coli, only a small amount of thrombin is active due to the formation of inclusion bodies (Freydell et al. 2007; Silaban et al. 2016).

Inclusion bodies is a dynamic structure that formed by an imbalance between the aggregates and soluble proteins from $E$. coli. Inclusion bodies formation can be caused by the partially folding of polypeptides. It occurs as are suil of accumulation of partial folding proteins that have been expressed in the aggregates forms through non-covalent hydrophobic interactions, ionic interactions, or both (Rizkia et al. 2015; Silaban et al. 2018). The formation of inclusion bodies in recombinant protein expression in $E$. coli can be minimized by reducing the temperature and expression rate during the production process (Freydell et al. 2007; Hartinger et al. 2010).

\section{Materials and Methods}

\section{Strains, chemicals, vector and medium}

Transformation and cloning was performed using E. coli TOP1OF' (Invitrogen, USA). E. coli BL21(DE3) ArcticExpress expression host were gifts from Dr. Jiri Damborsky (Masaryk University, Brno, Czech Republic).The hosts were cultivated in Luria Bertani medium, (1\% tryptone, 0.5\% yeast extract, and $1 \%$ sodium chloride) supplemented by appropriate antibiotics (tetracycline 100 $\mu \mathrm{g}$ mL-1 or ampicillin $100 \mu \mathrm{g}$ mL-1). Luria Bertani medium with addition of $2 \%$ agar was used as solid medium. All restriction enzymes, T4 DNA ligase, and pTWIN1 expression vector were purchased from New Englands (New England Biolabs, USA). Human prethrombin-2 (hPT-2) gene was commercially synthesized by GeneArt (Life Technologies, Germany). Isolation kit (Roche Applied Science, USA) and gene extraction kit (Geneaid, Taiwan) were purchased commercially. lsopropyl- $\beta$-D-thiogalactoside (IPTG) and $\beta$-mercaptoethanol $(\beta M E)$ were from Sigma Aldrich (Sigma Aldrich, USA). Polyacrilamide and Commasie Brilliant Blue were from Biorad (BioRad, Richmond, USA).

\section{Transformation of E. coli BL21(DE3) ArcticExpress using pTWINI-hPT-2 plasmid}

Plasmid pTWINi-hPT-2 was isolated from E. coli TOPIOF', then used to transform the competent expression host cells.A total of $5 \mu \mathrm{L}$ pTWINI-hPT-2 was added to the microtube containing $100 \mu \mathrm{L}$ competent cells, and then incubated for $30 \mathrm{~min}$ at $-4^{\circ} \mathrm{C}$. Heat shock was carried out at $42^{\circ} \mathrm{C}$ for 90 seconds, then was immediately cooled on ice for 10 minutes. This mixture was added to 900 $\mu \mathrm{L}$ of liquid $\mathrm{LB}$ medium and was incubated at $37^{\circ} \mathrm{C}$ for $2 \mathrm{~h}$ with agitation rate of $150 \mathrm{rpm}$. Centrifugation was performed at $12,000 \mathrm{~g}$ for 1 min seconds. A total of $900 \mu \mathrm{L}$ supernatant was removed, and the remaining of $100 \mu \mathrm{L}$ of mixture was grown in $\mathrm{LB}$ medium containing $10 \mu \mathrm{g} / \mathrm{mLof}$ 
tetracycline, $10 \mu \mathrm{g} / \mathrm{mL}$ of ampicillin and $20 \mu \mathrm{g} / \mathrm{mL}$ of gentamicin, and then incubated at $37^{\circ} \mathrm{C}$ for 18 hours(Sambrook and Russell, 2001).

Transformation of $E$. coli that grows was $E$. coli which has brought recombinant plasmids. To ensure that $E$. coli transforman had carried the correct recombinant plasmid, then analysis was carried out through recombinant plasmid isolation from $E$. coli transformants, restriction analysis and determination of hPT-2 nucleotide sequences.

\section{hPT-2 Expression with induction temperature variation}

Preliminary test of rhPT-2 fragment expression in E. coli BL21(DE3) ArcticExpress was carried out by growing $E$. coli $\mathrm{BL21}(\mathrm{DE} 3)$ ArcticExpress [pTWINi-hPT-2]. A total of $1 \%(\mathrm{v} / \mathrm{v})$ inoculates culture E. coli BL21(DE3) ArcticExpress carried pTWINı-hPT-2 was grown in a medium containing 10 $\mu \mathrm{g} / \mathrm{mL}$ of ampicillin. Induction was done by using concentration of IPTG $0.1 \mathrm{mM}$, with agitation rate of $100 \mathrm{rpm}$ at a temperature variation of $12^{\circ} \mathrm{C}$ and $22^{\circ} \mathrm{C}$. Cells were harvested after 18 hours of incubation. Cell debris was separated from the supernatant by centrifugation at $12.000 \mathrm{~g}$ speeds. hPT-2 expression results in the supernatant and cell debris were characterized using $12 \%$ SDSPAGE (Bollag et al. 1996).

\section{Results}

\section{Isolation of pTWINI-hPT-2 from E. coli TOPIOF'}

Plasmid isolation of pTWINi-hPT-2 from E. coli TOPIOF cells was carried out using a plasmid isolation kit (Geneaid). To ensure that the isolation process was successfully carried out, then pTWINI-hPT-2 plasmid was characterized using one enzyme (Ndel) and two enzymes (Ndel and Xhol). Characterization results using this enzyme, then characterized by electrophoresis using $1 \%$ agarose gel (Fig 1). Characterization results using one enzyme obtained a linear band measuring $7633 \mathrm{bp}$ in accordance with the size of recombinant plasmid (Fig 1A lane 1). While the characterization using two enzymes obtained two bands measuring $6697 \mathrm{bp}$ as pTWINi (Fig IB lane 2) and $936 \mathrm{bp}$ as hPT-2 fragments (Fig $1 \mathrm{~B}$ lane 3).
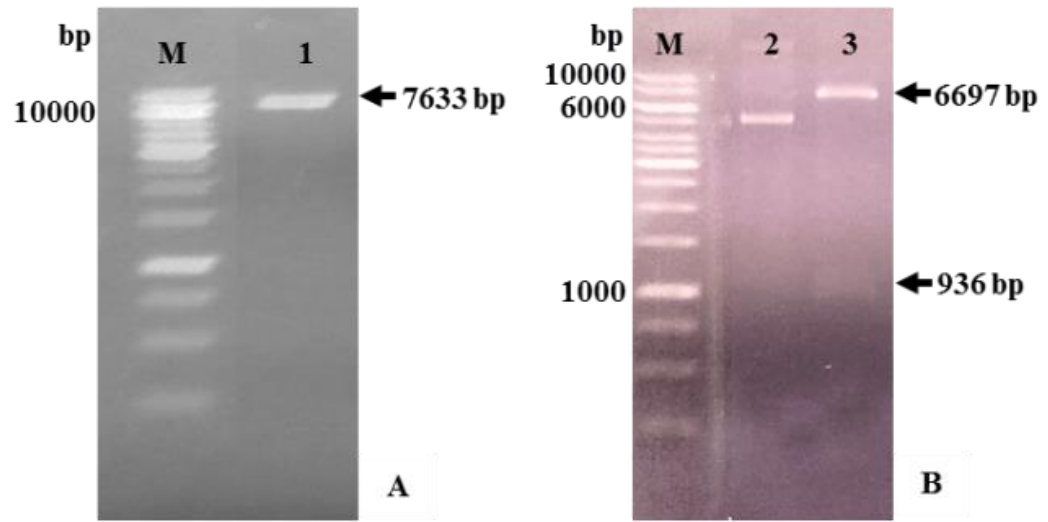

Fig 1. Isolation analysis of pTWINI-hPT-2 from E. coli TOP10F' by using $1 \%$ agarose gel electrophoresis. M: 1 kb DNA marker; line 1 figure $1 \mathrm{~A}: \mathrm{pTWINı}-\mathrm{hPT}-2$ was cut with BamHI; line 2 figure $1 \mathrm{~B}$ : pTWINIhPT-2; line 3 figure IB: double-digested plasmid resulting pTWINı and rhPT-2.

\section{Transformation of E. coli BL21 (DE3)Arctic Express}

The E. coli strain BL21(DE3) ArcticExpress was transformed by inserting the pTWIN1-hPT2 plasmid, so that for the next phase the cell can produce hPT-2 protein. Selection of transformants in this research was conducted using tetracycline, ampicillin and gentamicin antibiotic resistance. The pTWINi-hPT-2 plasmid carrying the gene encode enzyme which can degrades ampicillin, so the cells that able to absorb the plasmid will survive, while the others will be dead. The E. coli BL21(DE3) ArcticExpress which carry pTWINI-hPT-2 were grown in LB medium. Colonies which 
can grow on selection media (Fig 2A), were grown back in liquid LB medium and isolated as shown in Fig $2 \mathrm{~B}$.

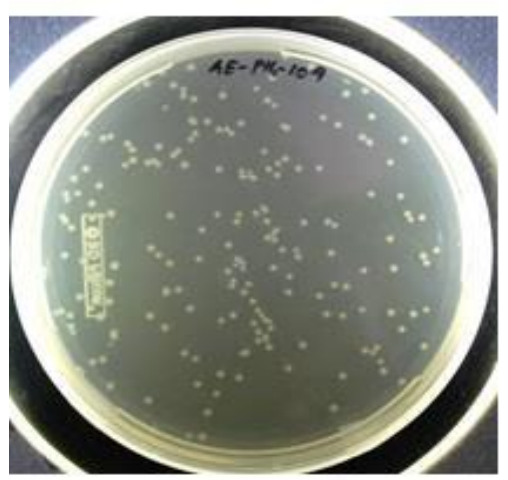

A

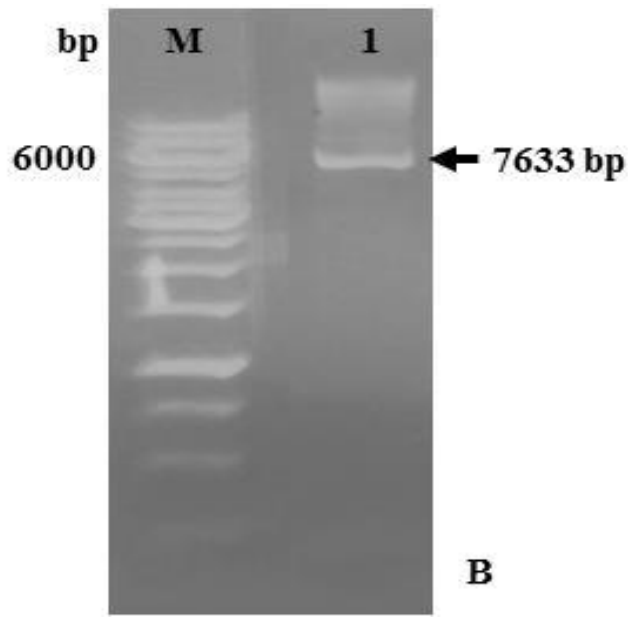

Fig 2. Transformants analysis by using $1 \%$ agarose gel electrophoresis. $2 \mathrm{~A}$ : transformants $E$. coli $\mathrm{BL21}(\mathrm{DE} 3)$ ArcticExpress carrier of pTWINi-hPT-2 plasmid. 2B: isolation results of pTWINi-hPT-2 from $E$. coli BL21(DE3) ArcticExpress M: 1 kb DNA marker; line 1 figure 2B: pTWINı-hPT-2.

\section{hPT-2 expression in E. coli BL21 (DE3)Arctic Express}

The effect of induction temperature were investigated.The effect of induction temperature were investigated. The inducer used in our experiment was IPTG. IPTG inducer is a critical factor for gene expression in E. coli host (Moradian et al. 203; Rizkia et al. 2015; Wang et al. 2018; Silaban et al. 2019).The cells culture was induced using IPTG with a final concentration of $0.1 \mathrm{mM}$, and incubated for 16 hours at temperature variations of 12 and $22^{\circ} \mathrm{C}$. The rhPT-2 was designed as fusion protein. The total molecular weight of fusion protein was $63 \mathrm{kDa}$. The protein expression was analyzed by $12 \%$ SDS-PAGE.The results showed that induction temperature $12^{\circ} \mathrm{C}$ for expression of E. coli BL21(DE3) ArcticExpress could increase soluble CBD-Intein rhPT-2 fusion protein (Fig 3A line 2). In contrast, induction temperature $22^{\circ} \mathrm{C}$ unable to increase rhPT-2 fusion protein insoluble form (Fig 3B line 2).
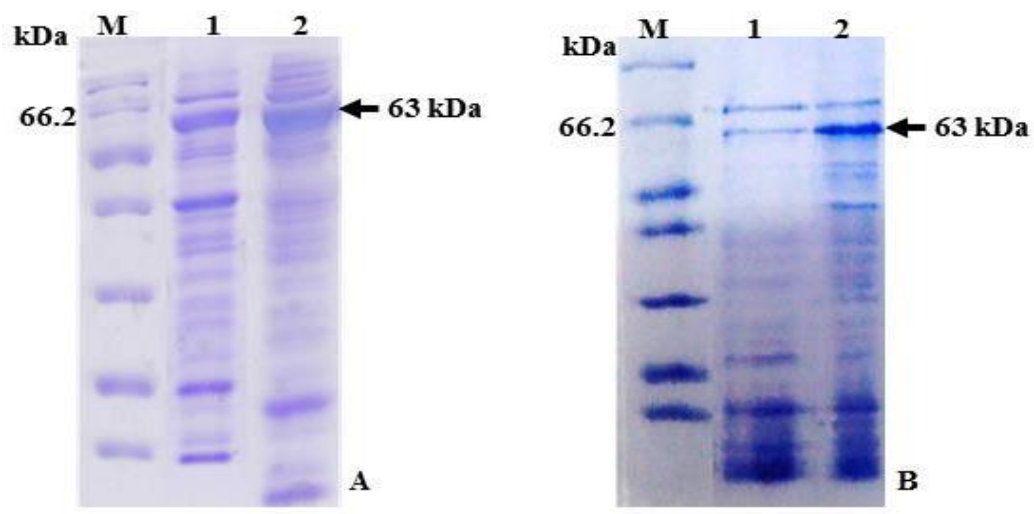

Fig 3. SDS-PAGE analysis of protein expression of CBD-Intein-rhPT-2 with temperature variations. 3A: $12^{\circ} \mathrm{C}$ induction temperature. $3 \mathrm{~B}: 22^{\circ} \mathrm{C}$ induction temperature. M: molecular weight marker; line 1 figure 3A \& 3B: the insoluble fraction; line 2 figure 3A \& 3B:soluble fraction of CBD-Intein-rhPT-2 fusion protein. 


\section{Discussion}

Formation of inclusion bodies in $E$. coli is a major problem in the expression of recombinant protein (Freydell et al. 2007). Although it may also offer an advantage, that it is easily purified, as long as the protein can latter be refolded (Singh and Panda 2005). However, refolding involves multistep processes and the recovery of correctly folded and active enzyme are still uncertain (Soejima et al. 2001).

Bacterial growth and recombinant protein expression are influenced by several parameters, such as the composition of the medium, oxygen content, $\mathrm{pH}$, fermentation temperature and induction (Freydell et al. 2007; Hartinger et al. 2010). lt is well-known that E. coli is the most widely used and suitable host of heterologous proteins at $21-49^{\circ} \mathrm{C}$, with an optimum at abou $37^{\circ} \mathrm{C}$ (Ferrer et al. 2003), but when high expression of protein is needed, the $E$. colis capability to accurately express recombinant proteins decreased, and inclusion bodies can be formed. Low temperature has been proposed to improve protein solubility, but slower growth and low synthesis rates may downgrade protein yields (Sorensen and Mortensen 2005).

From two temperature variations, only at $12^{\circ} \mathrm{C}$, more soluble proteins are produced, while the induction temperature of $22^{\circ} \mathrm{C}$ produces insoluble proteins. Thus, a high amount of soluble fusion protein rhPT-2 in E. coli BL21(DE3) ArcticExpress can be achieved at an optimum temperature of $12^{\circ} \mathrm{C}$. This success was allegedly influenced by the presence of a chaperon ( $\mathrm{CPn} 60$ / Cpn10) carried by E. coli BL21(DE3) ArcticExpress host. These chaperones display high refolding activities and govern growth of $E$. coli at low temperatures (Ferrer et al. 2004; Strocchi et al. 2006). As expected, expression analyses demonstrated that E. coli BL21(DE3) ArcticExpress could produce rhPT-2 in soluble form.

\section{Conclusion}

It can be concluded that the synergy among low induction temperature and $E$. coli BL21(DE3) ArcticExpress as a host, could be used to successfully produce a soluble form of rhPT-2.

\section{Acknowledgments}

This research was funded by Directorate General of Research and Development Strengthening, Ministry of Technology Research and Higher Education, Republic of Indonesia, through skim "Penelitian Terapan Unggulan Perguruan Tinggi (PTUPT)" with a contract No. 60/UN33.8/PLDRPM/2019) Year 2019.

\section{References}

Bishop, P., Lewis, K., Schultz, J., \& Walker, K. (2006). Comparison of recombinant human thrombin and plasma-derived human $\alpha$-thrombin. Seminars in Thrombosis and Hemostasis, 32(S 1), 086-097, doi: $10.1055 / \mathrm{s}-2006-939558$

Bollag, D. M., Rozycki, M. D., \& Edelstein, S. J. (1996). Protein method. $2^{\text {nd }}$, John Wiley \& Sons, Inc. USA.

Bonatti, J. A., Bechara, S. J., Dall'Col, M. W. L., Cresta, F. B., Carricondo, P. C., \& Kara-José, N. (2007). A fibrin-related line of research and theoretical possibilities for the use of fibrin glue as a temporary basal membrane in non-perforated corneal ulcers and in photorefractive keratectomy (PRK)-operated corneas. Arquivos Brasileiros de Oftalmologia, 70(5), 884-889, doi: 10.1590/s000427492007000500029

Cabrita, L. D., Dai, W., \& Bottomley, S. P. (2006). A family of E. coli expression vectors for laboratory scale and high throughput soluble protein production. BMC Biotechnology, 6, 12, doi: 10.1186/1472-6750-612

Choi, E. H. (1989). Cloning and expression of human prethrombin 2 cDNA in Escherichia coli. Korean Biochem. J., 22, 154-160. 
Chen, R. (2012). Bacterial expression systems for recombinant protein production: $E$. coli and beyond. Biotechnology Advances, 30(5), 1102-1107, doi: 10.1016/j.biotechadv.2011.09.013

Côté, H. C., Stevens, W. K., Bajzar, L., Banfield, D. K., Nesheim, M. E., \& MacGillivray, R. T. (1994). Characterization of a stable form of human meizothrombin derived from recombinant prothrombin (R155A, R271A, and R284A). Journal of Biological Chemistry, 269(15), 11374-11380.

DiBella, E. E., Maurer, M. C., \& Scheraga, H. A. (1995). Expression and folding of recombinant bovine prethrombin-2 and its activation to thrombin. Journal of Biological Chemistry, 270(1), 163-169, doi: 10.1074/jbc.270.1.163

Ferrer, M., Chernikova, T. N., Yakimov, M. M., Golyshin, P. N., \& Timmis, K. N. (2003). Chaperonins govern growth of Escherichia coli at low temperatures. Nature Biotechnology, 21(11), 1267-1267, doi: 10.1038/nbt1103-1266b

Ferrer, M., Chernikova, T. N., Timmis, K. N., \& Golyshin, P. N. (2004). Expression of a TemperatureSensitive Esterase in a Novel Chaperone-Based Escherichia coli Strain. Applied and Environmental Microbiology, 70(8), 4499-4504, doi: 10.1128/aem.70.8.4499-4504.2004

Freydell, E. J., Ottens, M., Eppink, M., van Dedem, G., \& van der Wielen, L. (2007). Efficient solubilization of inclusion bodies. Biotechnology Journal: Healthcare Nutrition Technology, 2(6), 678-684, doi: 10.1002/biot.200700046

Hartinger, D., Heinl, S., Schwartz, H., Grabherr, R., Schatzmayr, G., Haltrich, D., \& Moll, W.-D. (2010). Enhancement of solubility in Escherichia coli and purification of an aminotransferase from Sphingopyxis sp. MTAl44 for deamination of hydrolyzed fumonisin Bl. Microbial Cell Factories, 9(1), 62, doi: 10.1186/1475-2859-9-62

Jonebring, A., Lange, U., Bucha, E., Deinum, J., Elg, M., \& Lövgren, A. (2012). Expression and characterization of recombinant ecarin. The Protein Journal, 31(5), 353-358, doi: 10.1007/s10930-012-9409-6

Laurens, N., Koolwijk, P. D., \& De Maat, M. P. M. (2006). Fibrin structure and wound healing. Journal of Thrombosis and Haemostasis, 4(5), 932-939, doi: 10.1111/j.1538-7836.2006.01861.x

Moradian, C., Fazeli, M., \& Abedi, D. (2013). Over expression of the Interferon $\beta$-lb by optimizing induction conditions using response surface meth-odology. Journal of Biology and Today's World, 2(4), doi: $10.15412 / j . j b t w .01020401$

Osadská, M., Boňková, H., Krahulec, J., Stuchlík, S., \& Turňa, J. (2014). Optimization of expression of untagged and histidine-tagged human recombinant thrombin precursors in Escherichia coli. Applied Microbiology and Biotechnology, 98(22), 9259-9270, doi: 10.1007/s00253-014-5840-2

Owen, W. G., Esmon, C. T., \& Jackson, C. M. (1974). The conversion of prothrombin to thrombin 1. Characterization of the reaction products formed during the activation of bovine prothrombin. Journal of Biological Chemistry, 249(2), 594-605.

Rizkia, P. R., Silaban, S., Hasan, K., Kamara, D. S., Subroto, T., Soemitro, S., \& Maksum, 1. P. (2015). Effect of Isopropyl- $\beta$-D-thiogalactopyranoside concentration on prethrombin-2 recombinan gene Expression in Escherichia coli ER2566. Procedia Chemistry, 17, 118-124, doi: 10.1016/j.proche.2015.12.121

Russo, G., Gast, A., Schlaeger, E.-J., Angiolillo, A., \& Pietropaolo, C. (1997). Stable expression and purification of a secreted human recombinant prethrombin-2 and its activation to thrombin. Protein Expression and Purification, 10(2), 214-225, doi: 10.1006/prep.1997.0733

Sambrook, J. E. F., \& Russell, D. W. (2001). Molecular cloning: A laboratory manual. 3rd Ed. Cold Spring Harbor Laboratory Press. New York.

Silaban, S., Maksum, I. P., Ghaffar, S., Hasan, K., Enus, S., Subroto, T., \& Soemitro, S. (2014). Codon optimization and chaperone assisted solubilization of recombinant human prethrombin-2 expressed in Escherichia coli. Microbiology Indonesia, 8(4), 177-182, doi: 10.5454/mi.8.4.5

Silaban, S., Maksum, I. P., Enus, S., Hasan, K., Subroto, T., \& Soemitro, S. (2016). Kajian ekspresi gen pretrombin-2 manusia sintetik pada Escherichia coli secara in silico untuk produksi trombin sebagai komponen lem fibrin. J. Pendidikan Kimia, 8(1), 58-64.

Silaban, S., Maksum, l. P., Hasan, K., Enus, S., Subroto, T., \& Soemitro, S. (2017). Purification of recombinant human pretrombin-2 in Escherichia coli for thrombin production as fibrin glue components. J. Pendidikan Kimia, 9(1), 265-272, doi: 10.24114/jpkim.v9i1.6201 
Silaban, S., Gaffar, S., Simorangkir, M., Maksum, 1. P., \& Subroto, T. (2018). Effect of IPTG Concentration on Recombinant Human Prethrombin-2 Expression in Escherichia coli BL21(DE3) ArcticExpress. IOP Conference Series: Earth and Environmental Science, 217, 012039, doi: 10.1088/1755-1315/217/1/012039

Silaban, S., Gaffar, S., Simorangkir, M., Maksum, l. P., \& Subroto, T. (2019). Construction and optimization of prethrombin-2 human genes in E. coli for the production of active thrombin. Journal of Physics: Conference Series, 1374, 012047, doi :10.1088/1742-6596/1374/1/012047

Singh, S. M., \& Panda, A. K. (2005). Solubilization and refolding of bacterial inclusion body proteins. Journal of Bioscience and Bioengineering, 99(4), 303-310, doi: 10.1263/jbb.99.303

So, 1. S., Lee, S., Kim, S. W., Hahm, K. S., \& Kim, J. (1992). Purification and activation of recombinant human prethrombin 2 produced in E. coli. Korean Biochemical Journal, 25(1), 60-65.

Soejima, K., Mimura, N., Yonemura, H., Nakatake, H., Imamura, T., \& Nozaki, C. (2001). An efficient refolding method for the preparation of recombinant human prethrombin-2 and characterization of the recombinant-derived $\alpha$-thrombin. Journal of Biochemistry, 130(2), 269-277, doi: 10.1093/oxfordjournals.jbchem.a002982

Spotnitz, W. D., \& Prabhu, R. (2005). Fibrin sealant tissue adhesive - Review and update. Journal of LongTerm Effects of Medical Implants, 15(3), 245-270, doi: 10.1615/jlongtermeffmedimplants.v15.i3.20

Sørensen, H. P., \& Mortensen, K. K. (2005). Advanced genetic strategies for recombinant protein expression in Escherichia coli. Journal of Biotechnology, 115(2), 113-128, doi: 10.1016/j.jbiotec.2004.08.004

Strocchi, M., Ferrer, M., Timmis, K. N., \& Golyshin, P. N. (2006). Low temperature-induced systems failure inEscherichia coli: Insights from rescue by cold-adapted chaperones. Proteomics, 6(1), 193-206, doi: 10.1002/pmic.200500031

Subroto, T., Pertiwi, W., Fadhillah, M., Hasan, K., Budiantoro, O., Enus, S., \& Soemitro, S. (2016). Cloning, expression, and functional characterization of autoactivated human prethrombin-2 synthetic gene by Using Pichia pastoris SMDı68 As a Host. Microbiology Indonesia, 10(2), 39-47, doi: 10.5454/mi.10.2.1

Wang, Y., Wang, Z., Duo, Y., Wang, X., Chen, J., \& Chen, J. (2018). Gene cloning, expression, and reducing property enhancement of nitrous oxide reductase from Alcaligenes denitrificans strain TB. Environmental Pollution, 239, 43-52, doi: 10.1016/j.envpol.2018.04.005

Yonemura, H., Takayuki, I., Kenji, S., Yo, N., Wataru, M., Yoshitaka, U., Yasuharu, K., Hiroshi, N., Keishin, S., Tomohiro, N., \& Chikateru, N. (2004). Preparation of recombinant $\alpha$-thrombin: high-level expression of recombinant human prethrombin-2 and its activation by recombinant ecarin. J. Biochem, 135(5), 577-582, doi: 10.1093/jb/mvh070 